International Review of Social History 46 (2001), pp. 29-44

(C) 200 I Internationaal Instituut voor Sociale Geschiedenis

\title{
Pawning in German Working-Class Life Before the First World War
}

\author{
KARL CHRISTIAN F ÜHRER
}

Summary: This essay looks at the patterns of pawning in Germany in the decades preceding the First World War. It tries to present pawning and thus also the economy of nineteenth-century working-class households in a new light. Contrary to the generally accepted view of social historians, it is unlikely that pawning served to secure the proletarian household in periods of real hardship. There is much evidence that pawning was only considered when it seemed very likely that the borrower would be able to redeem the pledge in due course. It was therefore part of a rather stable economic situation. Insecurity of prospects persuaded people to refrain from pawning. Pawnshops thrived not on working-class destitution, but on the very modest "affluence" proletarian families were able to achieve in the era of industrialization. The striking differences between the patterns of pawning in Germany and in Great Britain therefore point to significant differences in proletarian standards of living between the two societies in question.

It is a well-established fact among social historians of working-class life in the nineteenth and early twentieth century that pawning was of crucial importance for the economy of proletarian households: it helped them to make ends meet in times of hardship. Paul Johnson has put it this way in his Saving and Spending: The Working-Class Economy in Britain, I8701939: "The unpredictable nature of sickness and death ensured some regular business for pawnbrokers. [...]. The temporary unemployment which afflicted most manual workers other than a fortunate few [...] was also the cause of pawning, especially so in ports with their large pool of casual dock labour." I

However, the evidence for this generally accepted view of pawning as a financial remedy in times of individual economic crisis is exclusively drawn from British sources. As will be demonstrated in this essay, a look at different material - in this case from Germany in the decades preceding the First World War - might well lead to different conclusions in some

I. Paul Johnson, Saving and Spending: The Working-Class Economy in Britain, I870-1939 (Oxford, I985), p. I74. Compare also Melanie Tebbutt, Making Ends Meet: Pawnbroking and Working-Class Credit (New York, I984). 
crucial points that present pawning, and thus also the economy of nineteenth-century working-class households, in a rather different light. ${ }^{2}$ The essay is organized in two parts. First I will try to compile information on pawning in Germany in the era of industrialization between I 870 and I9I 4 and present the patterns of pawning that can be deduced by looking at this material. In a second part I will offer some suggestions for conclusions that can be drawn from the presented facts. In my view they prompt us to reconsider the importance of pawning in working-class life in the decades before the First World War and also draw attention to the lack of comparative studies on the proletarian way of living in European societies.

\section{PATTERNS OF PAWNING}

The basic rules of pawning are virtually the same nowadays as they were in the nineteenth century: pawnbrokers advance loans against the security of goods and chattels. For the term of the contract they store the pawned portable property of the borrower who can redeem the pledge at any time in this period by repayment of capital loaned and interest due on the loan. In case the pledge is still unredeemed when the contract expires the pawned good is either forfeited by its owner - which means that it becomes the outright property of the pawnbroker and that he is allowed to sell it - or the contract is renewed by payment of interest due. In the latter case the borrower safeguards once again his right of possession; in the earlier case there is still a chance of redemption until the pledge has finally been sold by the pawnbroker.

The easiest way to demonstrate that this special form of credit must have been of different importance in British and German working-class life in the years before the First World War is to point to the respective number of pawnbrokers in these two countries. In I895 4,537 pawnshops were licensed in Great Britain. They abounded in the big cities, especially in proletarian neighbourhoods. ${ }^{3}$ In Germany the situation was quite different: in the same year only I,07 I such enterprises operated in the whole

2. Very little about pawning is to be found in scholarly writings on German working-class history. For example, it is not mentioned at all in a recent synthesis of most of the findings of the "new" social history of the last two decades. Compare Gerhard A. Ritter/Klaus Tenfelde, Arbeiter im Deutschen Kaiserreich 1871 bis 1914 (Bonn, I992), and Paul Thomes, "Zwischen Pump und Sparen - Unterschichtenhaushalte in der Industrialisierung”, in Toni Pierenkemper (ed.), Zur Ökonomik des privaten Haushalts. Haushaltsrechnungen als Quelle historischer Wirtschafts- und Sozialforschung (Frankfurt [etc.], I98 I), pp. 240-252. Still the only discussion of the topic is the author's own contribution: Karl Christian Führer, "Das Kreditinstitut der kleinen Leute: Zur Bedeutung der Pfandleihe im deutschen Kaiserreich”, Zeitschrift für Bankengeschichte, 1992, pp. 3-21.

3. Johnson, Saving, p. I70. 
Reich although there were some twenty million more Germans than inhabitants of the British Isles. ${ }^{4}$ Even in a big city such as Hamburg Germany's most important harbour, its second greatest town with a "large pool of casual dock labour" - pawnshops were comparatively rare: in I 882 Hamburg's destitutes could choose only among twenty-four pawnbrokers; in 1902 this figure had risen to forty-six. Since the number of Hamburg's inhabitants had almost doubled in these two decades, things were still very different from comparable British cities: on average the ratio of pawnshops per inhabitant was roughly 4,000 in British industrial cities while in Hamburg this figure amounted to 19,795 in 1892 and to 17,458 in 1902. Unfortunately no precise comparison is possible in the number of clients and pledges, but the scarce evidence that we have suggests strongly that also these figures were very different in both countries. Paul Johnson estimates that British provincial pawnshops on average took in 40,000 pledges annually during the years preceding the First World War and business in London was even better (60,000 pledges per year). In contrast, statisticians in I9I 2 ascertained that on average only 22,464 goods and chattels were pledged in Hamburg's then sixty-three pawnshops. ${ }^{5}$ Of course Hamburg could not compare itself with London, but with a population of slightly more than one million people it was then a bigger city than all the other British towns. Nevertheless, the scale of the business of pawnbroking seems to have been far more modest than even in Britain's hinterland.

In other German towns pawnbroking was even less accessible for customers-to-be than in Hamburg. Pawnshops were extremely rare, especially in fast growing new industrial cities where workers formed the great majority of the population: Bochum for example - a town of I 23,000 people - had only one pawnshop in 1907; there were three in Krefeld and in Dortmund respectively, seven in Gelsenkirchen. The same was true of Saxony's industrial centres such as Chemnitz (eight pawnshops in 1907) or Plauen (two shops). ${ }^{6}$ At best there was one pawnbroker for every 20,000-30,000 people in these towns; in other cases (Bochum, Plauen, Dortmund) this ratio was even more unfavourable ( 53,000 people per pawnshop in Plauen, 62,000 in Dortmund). None of these figures can compare with the number given above for British towns. A possible explanation for this difference might be that pawnshops in Germany were

4. Statistik des Deutschen Reiches, vol. 22 I (Berlin, 1909), p. I 8. Only 977 of these shops traded exclusively in pawnbroking, 177 were combined with a different trade (Nebengewerbe).

5. Figures from Tabelle betr. die hamburgischen Pfandleihgeschäfte, without date, Staatsarchiv (StA) Hamburg, Senat Cl.VII Lit.C c nr. 5, vol. 67, conv. I. These figures include Hamburg's municipal pawnshop, the Staatspfandleihe. For figures for Britain, compare in Johnson, Saving, pp. 168 and 170.

6. Statistik des Deutschen Reiches, vol. 217 (Berlin, I909), pp. I 50, I 58, 165, 203, 266, 308, 3 I8, 327. 
perhaps rarer since pawning was here - unlike in Britain - big business, but this was not the case. Typically, the pawnshops in Germany's industrial cities were very small enterprises: the pawnshop in Bochum was run solely by its proprietor, the seven shops in Gelsenkirchen employed only eight people.7 Only one German city could boast of a situation at least comparable to that in Britain: in 1907 the ratio of people per pawnshop was at roughly 5,200 in Munich. ${ }^{8}$

The fact that pawnbroking enterprises were so much less common and also less busy in Germany than in Great Britain is even more puzzling since the business was publicly controlled along virtually the same lines in both countries. In 1872 the British "Pawnbroker Act" restricted the rate of interest pawnbrokers were allowed to ask for to twenty-five per cent per annum at the most for smaller loans up to $£_{2} .{ }^{9}$ Seven years later, Germany followed on: in 1879 the Reichstag granted the German states the right to impose binding regulations for pawnbroking. Most state governments made use of this new right and fixed - among other things - a maximum rate of interest. While 20 per cent per annum or more had been quite common before this public intervention, it was now more often than not restricted to twenty-four per cent (two per cent per month) for smaller loans. Even less - eighteen and twelve per cent per annum respectively were permitted in Baden and in Bavaria. ${ }^{\circ}$ However, there was one significant difference in the public regulation of pawning in the two countries: German municipal authorities could - unlike their British counterparts - prevent the establishment of new pawnshops if they saw no "public need" (öffentliches Interesse) for them. In translating this into action, most cities seem to have been quite draconian, since they had to guard the interests of public enterprise: unlike their British colleagues German pawnbrokers had to face competition from municipal pawnshops. These were designed or remodelled - some of them had a centuries-old, if less charitable, history - according to public-spirited rules. For example the Hamburg state pawnshop (Staatspfandleibe) was expressly advised by the Senate "to offer help to those in need who are short of funds and to lead them away from transactions at private pawnshops". ${ }^{\text {II }}$

Not surprisingly, public pawnbroking did not meet with general acclaim among the German bourgeoisie. One especially fervent advocate of a free market economy castigated the "plague of public pawnshops". In this

7. Ibid., pp. I 58,165 .

8. Calculated on the basis of ibid., p. 276; Statistisches Jabrbuch Deutscher Städte, vol. I 8 (Berlin, I9I 2), pp. 680-68I.

9. Johnson, Saving, p. I66. Only twenty per cent was permitted for loans over $£_{2}$.

Io. W.R. Patterson, "Die gegenwärtige Lage der Leihämter in Deutschland", Jabrbücher für Nationalökonomie und Statistik, third series, vol. Is (Berlin, I898), pp. 2 I I-232, 213-2 I9.

I I. Instruktion für die Verwalter der Staatspfandleihhäuser, April i892, StA Hamburg Finanzdeputation IV St.L. I B 4 a. 
view, usurious rates of interest had an educational purpose: they taught members of the lower classes to balance their budgets, while making credit less expensive and more easily accessible was an enticement for a carefree and irresponsible way of living. ${ }^{12}$ Even Gustav Schmoller, one of Germany's most eminent middle-class social reformers, at least partly shared this opinion: he complained that inexpensive public pawnbroking might help not just the "worthy" but also the "dissipated poor" and wanted to impose higher rates of interest on the later. ${ }^{\mathrm{I}}$

But these reservations vanished with the upturn of German "municipal socialism" in the last decades of the century. Striving for the improvement of the living conditions of all citizens, but especially of those of the working-class that were still to be integrated into the political system of the Kaiserreich, more and more municipal authorities in the Reich established a far-reaching system of social institutions. ${ }^{I 4}$ The public pawnshop became an almost essential part of communal welfare: in I 892 I 44 German towns - among them virtually all big cities - had established a municipal Pfandleibe. More often than not the rate of interest customers of such a public enterprise had to pay was less excessive than the twentyfour per cent per annum private pawnbrokers were allowed since i 879 . Rates ranged between twelve and eighteen per cent per annum in most cases, but some cities - Nürnberg, Mannheim, Wiesbaden and Metz demanded only ten per cent or even less. ${ }^{15}$ Most probably the existence of these inexpensive competitors and the obligation of a public license kept private pawnbroking - which was an expensive and chancy business more at bay in Germany than in Great Britain.

It might be argued that the fact that the modern welfare state had reached a far more advanced stage of development in Germany than in Great Britain in the last decades of the nineteenth century must also have contributed to the different development of pawning in these two societies, but I would argue that this would overestimate by far the practical effects of the Bismarckian social insurance legislation passed between I 883 and I $889 .{ }^{16}$ As has recently been pointed out by many

I2. Moritz Mohl, Die Pest öffentlicher Leibhäuser (Stuttgart, I866), p. 35 .

I3. Gustav Schmoller, "Die öffentlichen Leihhäuser, sowie das Pfandleih- und Rückkaufsgeschäft überhaupt", Jabrbücher für Gesetzgebung, Verwaltung und Volkswirtschaft im Deutschen Reiche, new series, vol. 4 (Berlin, I880), pp. 87-I23; I Iff.

I4. Compare, for the background, George Steinmetz, Regulating the Social: The Welfare State and Local Politics in Imperial Germany (Princeton, NJ, 1993), pp. 188-203.

I5. Compare Patterson, Die gegenwärtige Lage, pp. 213-219.

I6. A comparable British system of compulsory social insurance was created only between 1908 and I9I I (with the exception of the Workmen's Compensation Act that dated from I 897). For a short survey of the development of the system of social insurance in both countries, compare Gerhard A. Ritter, Sozialversicherung in Deutschland und England. Entstehung und Grundzüge im Vergleich (München, 1983). 
scholars, the German insurance laws "primarily benefited the 'core' proletariat of manual workers who were employed, skilled and male". ${ }^{17}$ They could therefore neither be regarded as an answer to the "social question", nor did they solve the more clearly defined "workers question": contemporaries of the Kaiserreich were far more conscious than many social historians of the fact that Germany lacked any significant form of public assistance for the unemployed up to i918. The "Ghent system" of municipal subsidies for labour unions' unemployment assistance funds that some German cities adopted in the years immediately before the First World War may be an interesting example of the newly developing "protocorporatist social policy", but in terms of practical help for unemployed workers this scheme was an unqualified failure. ${ }^{18}$ The German system of compulsory social insurances therefore lacked sound foundations, since only stable employment secured the benefits of health and old age insurance. Besides this, the insurance authorities proved to be unable to offer reliable help in many cases of need due to restrictive regulations; even those who received help were often left with insufficient payments. ${ }^{19}$ Despite the efforts of Bismarckian social reform, the major risks of working-class life were therefore still painfully real for German workers in the late Kaiserreich. In 1909 the Imperial Statistical Bureau (Kaiserliches Statistisches Amt) characterized the situation of lower-class households as follows: "each unexpected loss of income [...] disturbs the equilibrium of the household budget". ${ }^{20}$ Therefore the question arises whether the surprisingly small number of pawnshops in Germany can be exclusively put down to the reign of local authorities in this segment of the

17. Steinmetz, Regulating the Social, p. 43 .

I8. Compare Karl Christian Führer, Arbeitslosigkeit und die Entstehung der Arbeitslosenversicherung in Deutschland 1902-I927 (Berlin, I990), pp. I I4- I I 8. In I9I3 thirteen German cities had adopted the "Ghent system", named after the Belgian city of Ghent, where the scheme had been introduced in 1900 . For an extensive discussion of the system as part of "proto-corporatist policy", see Steinmetz, Regulating the Social, pp. 203-2 I 4.

19. For an excellent survey of the deficiencies of the German social insurance system see Klaus Saul, "Wirtschafts- und sozialpolitische Grundlagen, Industrialisierung, Systemstabilisierung und Sozialversicherung. Zur Entstehung, politischen Funktion und sozialen Realität der Sozialversicherung des kaiserlichen Deutschland", Zeitschrift für die gesamte Versicherungswissenschaft, 69 (1980), pp. 177-198; for discrimination against women see Barbara Fait, "Arbeiterfrauen und familien im System sozialer Sicherheit. Zur geschlechterpolitischen Dimension der Bismarkschen Arbeiterversicherung”, Jabrbuch für Wirtschaftsgeschichte 1997, vol. I, pp. I71-205.

20. Erbebung von Wirtschaftsrechnungen minderbemittelter Familien im Deutschen Reich. Bearbeitet im Kaiserlichen Statistischen Amt, Abteilung für Arbeiterstatistik (Berlin, 1909), p. I $8^{*}$. Especially the physical wellbeing of the male breadwinner was of the upmost importance for the fortune of the proletarian family: any chronic disease resulted in social decline. Compare Richard Ehrenberg/Hugo Racine, Krupp'sche Arbeiterfamilien. Entwicklung und EntwicklungsFaktoren von drei Generationen Deutscher Arbeiter (Jena, I 191 2), pp. 387, 394. 
capitalist economy and to the competition of municipal pawnshops that offered lower rates of interest and thus probably lured customers away from private enterprises. As I would argue, a closer look at the peculiarities of the business of pawnbroking points to a different answer.

Hard evidence - statistics, studies based on thorough research etc. - for the history of pawning in Germany is scarce and scattered. However, the material allows for a rough outline of the patterns of pawning. Pawning was quite common, at least in the big cities, in the years before the First World War. In I9I 2 on average 4,666 credits were secured by goods each working day in Hamburg. ${ }^{21}$ In Munich the municipal pawnshop alone concluded 480,000 transactions in 1902; credits summed up to no less than 5.2 million Marks - a figure which equalled no less than one-third of the expenses of all health insurances in the whole of Bavaria in the same year. ${ }^{22}$

Despite these impressive figures very little is known about the attitudes people had towards pawning. Generally it was regarded as a business that carried with it a certain amount of stigma. So members of the Hamburg state parliament, the Bürgerschaft, in 1872 expressed their worries that visitors to the local public pawnshop had to ascend a long flight of steps before the eyes of the public. They feared that this might render the errand of pawning "even more distressful than it is anyway". ${ }^{23}$ As a rule private pawnshops took great pains to shield customers from observation: they were situated in rear buildings and in back alleys or they offered two entrances, one from the street and one from inside the house through the hall. ${ }^{24}$ Nevertheless, many borrowers still shied away. They used a gobetween to turn in their pledge. Domestic servants, children and baggage handlers were generally recognized by pawnbrokers to perform this task. ${ }^{25}$ Besides this there were commercial agents as well: for a fee of three or maybe five per cent of the gained credit they took the obviously onerous task of pledging on themselves. In Munich fifty-nine such agents were officially licensed in $1910 .{ }^{26}$ Although these facts point to a widespread desire to shroud the act of pawning in secrecy, it is open to debate if working-class people attributed the same sense of shame and loss of community standing to it as members of the middle classes. It may be

2I. Calculated on the basis of Tabelle (no. 5).

22. Statistisches Jabrbuch Deutscher Städte, vol. I4 (Berlin, 1907), pp. 328-331; Bayern im Lichte seiner hundertjährigen Statistik (Munich, 1933), p. 87.

23. Mitteilung des Senats an die Bürgerschaft betr. die Verhältnisse des Lombard, 8.8. 1872, StA Hamburg Senat Cl. VII Lit. C c nr. 5, vol. 32.

24. Lorenz Zach, Das Münchner Pfandleihgeschäft (Munich, I9I I), p. 89.

25. Oscar Hetzer, Das gegenwärtige öffentliche Leibhaus in Deutschland mit besonderer Berücksichtigung des Leipziger Leibhauses (staatswiss. Diss. Universität Tübingen, 1907), p. 75. 26. Zach, Pfandleihgeschäft, pp. 8I-90; Heinz Cuneus, Die öffentlichen Leibhäuser Deutschlands unter besonderer Berïcksichtigung der großen Institute (staatswiss. Diss. Universität Leipzig, I93I), pp. 4I-44. 
noticed that the examples of genuinely proletarian comments on this subject that have come down to us accept pawning quite placidly as a part of lower-class life. However, evidence is at least ambiguous, since these examples are extremely rare and they are not voices of members of the more respectable parts of the German working class who might have felt differently. ${ }^{27}$

In any case, the great majority of pawnbrokers' customers doubtless came from the lower strata of German society. This can be easily ascertained by a look at the value of pawned goods: the bulk of the trade was for very small sums. As a rule, shops did not accept pledges that took a credit of less than one or two Marks (although private enterprises were often less strict with this than municipal pawnshops). Most loans did not range very much higher that this minimum amount. In I9I0 nearly half of all credits of the Dresden Städtische Pfandleibe were less than five Marks each, three years later this portion was virtually the same at the Hamburg Staatspfandleibe. Also in I 913 some sixty per cent of all customers gained a loan of four Marks or less at the Augsburg municipal pawnshop. Only eight per cent of all pledges pawned in Augsburg could be described as "valuable": they secured a credit of more than ten Marks. ${ }^{28}$ During the last years before the First World War, five Marks equalled one or maybe two day's wages of a skilled male worker.

Typically enough, the value of pawned goods tended to decline over the course of years. In I 899/I 900 the average credit granted by the municipal pawnshop in Altona - a Prussian town bordering on Hamburg - was only 5.85 Marks while it had been 9.22 Marks in $\mathrm{r} 882 / \mathrm{r} 883 .{ }^{29}$ This decline was a consequence of industrial mass production that, on the one hand, made certain consumer goods more easily available for lower-income households, but diminished, on the other hand, the quality and durability of these items. This was especially true of clothes and watches. ${ }^{30}$

Not everything was pawnable. Perishable goods were dismissed even if they could - as cigars, for example - keep well for quite a long time. For

27. Compare the two conversations of Hamburg dock labourers overheard and put down by police agents, in Richard J. Evans (ed.), Kneipengespräche im Kaiserreich. Stimmungsberichte der Hamburger Politischen Polizei I892-1914 (Reinbeck, I989), pp. 45, 47.

28. Ritthausen, "Das Leihamt der Stadt Dresden", Zeitschrift für Kommunalwirtschaft und Kommunalpolitik, I (191 I), pp. 670-672, 671; Albert Saulacher, Die Geschichte über Gründung, Entwicklung und Verwaltung des Leihamtes der Stadt Augsburg von I573 bis 1917 nebst einem kurzen Beitrag zur Geschichte der Augsburger Privat-Pfandleiben and Pfandvermittler. Mit Genehmigung des Stadtmagistrats Augsburg verfaßt (Augsburg, 1918), p. 43.

29. Calculated on the basis of Bericht über die Gemeinde-Verwaltung der Stadt Altona in den Jabren I 863 bis 1900, 2.Teil (Altona, 1906), p. 593.

30. Compare Verwaltungsbericht des Magistrats Frankfurt/M. für I895/96, p. 477, cited after Statistisches Jabrbuch Deutscher Städte, vol. I7 (Berlin, I 898), p. I I6. For the same development in Great Britain compare Tebbutt, Making Ends Meet, p. I 3 I. 
hygienic reasons, several municipal pawnshops did not accept shoes and bed-sheets; books, paintings and furniture were rejected throughout, the earlier two since it was deemed too difficult to establish their value and too chancy to have them sold in case the borrower forfeited his goods, the latter due to lack of storage room. ${ }^{3 \mathrm{I}}$ The fact that furniture could not be pawned is of some importance for the social history of everyday life of the German working class: it is well known that many proletarian families took great pains to furnish and maintain a gute Stube - a parlour room that was very rarely used and remained locked for most of the year, even if this meant that the family was cramped up in the remaining rooms of the flat. At first glance it would be quite tempting to regard the stubbornness with which workers stuck to this habit, despite fierce criticism of the gute Stube expressed by bourgeois social reformers, at least as economically justified, in order to take this unused furniture as valuables to be converted into liquid assets when funds were required. But there was no such economic purpose to the gute Stube since pawnbrokers did not accept couches and sideboards as pledges. It served - at considerable cost - exclusively as a means to enhance community standing. ${ }^{32}$

Most common among pawned goods were jewellery and watches. In I 906 the Hamburg Staatspfandleibe took in 77,000 pieces of jewellery in gold and silver and 35,000 watches. Besides this, 31,000 garments, I 8,000 pieces of cloth, 2,000 bed-sheets, I,200 bicycles and 420 sewing-machines had been pawned. All in all, 170,000 different items were stored during this year. ${ }^{33}$ There is some evidence that wedding rings made up the greater part of pawned jewellery - an interesting point, since it hints at an altogether different proletarian attitude towards these symbols of matrimony that were emotionally so highly charged in the eyes of middle-class couples. ${ }^{34}$

As a pledge, jewellery offered one great advantage over other forms of portable property: at the same value it secured in comparison a greater loan. Municipal pawnshops paid out seventy-five or eighty per cent of the estimated value of pieces of jewellery, while all other pledges secured a credit of only fifty per cent of their respective value. ${ }^{35}$ Private enterprises seem to have paid higher rates, but the evidence for this is too scarce to be

3 I. Patterson, Die gegenwärtige Lage, p. 220.

32. Compare, for example, Heidi Rosenbaum, Proletarische Familien. Arbeiterfamilien und Arbeiterväter im frühen 20. Jahrhundert zwischen traditioneller, sozialdemokratischer und kleinbürgerlicher Orientierung (Frankfurt, 1992), pp. 174-179. According to Rosenbaum, the gute Stube served as a display of "respectability" that was intended to impress not only the equals of the family, but also the middle classes.

33. Eugen Würzburger, "Leihhäuser", in J. Conrad et al. (ed.), Handwörterbuch der Staatswissenschaften. 3. gänzlich umgearbeitete Auflage (Jena, I910), vol. 6, pp. 480-489, 486. 34. Führer, Das Kreditinstitut, p. I I.

35. Ritthausen, Das Leibamt, p. 671; Robert Schachner, "Die sozialpolitische Entartung der öffentlichen Leihhäuser”, Soziale Praxis, 20 (1910/I I), col. I297-1302, I 299. 
more precise..$^{36}$ In doing so they obviously took a high risk: at auctions of forfeited pledges only fifteen per cent of the items on offer sold at a profit at Hamburg private pawnshops. In contrast, at the Staatspfandleibe that continually urged its employees to be as cautious as possible in establishing the value of pledges and the amount of credit, the same figure was sixty per cent. ${ }^{37}$

It is open to speculation how these two different forms of business practice influenced customers-to-be: the municipal pawnshop most probably offered a smaller loan for the same pledge than its private competitors, but at the same time it asked, in most cases, for a considerably lower rate of interest. It seems plausible that people in urgent need of cash would not have worried too much about costs they had to pay some time in the future - which means that they would have opted for the greater loan and thus for the private pawnshop regardless of costs, but since we have virtually no evidence to judge how rational people decided in these matters, this may be a gross underestimation of their capacity for planning. On the other hand, given the insignificant value of most pawned goods, the difference between a loan from a public or a private pawnshop might not have been so very important in practice.

Various patterns of pawning in terms of time and season are discernible. While variations in the number of new pledges over the course of a week were not very great, credits were more often than not paid off on Saturdays when most workers received their weekly wage. The employees of the Hamburg Staatspfandleibe had to cope with a crowd of up to I,800 customers during the last three or four hours before closing time on each Saturday, most of them set on redeeming their pledges. ${ }^{38}$ At the Augsburg municipal pawnshop fifty-two per cent of all redemptions were settled on Saturdays in I91 3.39 This was not just a matter of available cash. It also expressed a desire for status. As has been shown above, most pledges were goods that - when publicly displayed - helped to improve or maintain social status: jewellery, watches, garments of higher quality. Obviously workers felt a desire to participate on their very moderate level in the ritualized forms of public wealth display in which the middle classes indulged every Sunday. This is borne out by the fact that the number of redemptions increased considerably just before the most important holidays such as Whitsun, All Saints Day (in Catholic regions) or Christmas. In Augsburg in I9I3 - to return to this example once again - I,476 pledges were redeemed prior to Whit Sunday and I,070 prior to All

36. Compare the vague remarks in Schachner, Entartung, col. I 300.

37. Stellungnahme des Lombard-Inspektors zum Gesetzentwurf betr. das Pfandleihergewerbe, without date, StA Hamburg Senat Cl.VII Lit.C c nr. 5, vol. 67, conv. I.

38. Ibid.

39. Saulacher, Geschichte, p. 74 . 


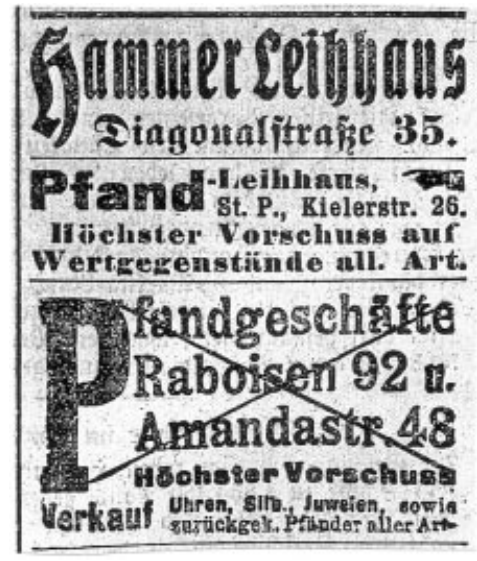

I

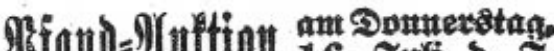

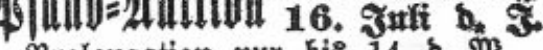 Brolongation nur bis 14 b. 9 . 1. Lienau \& Sohn, Snth.: Indwig Reimers, Barmber, Dejentifitrafte 43 .}

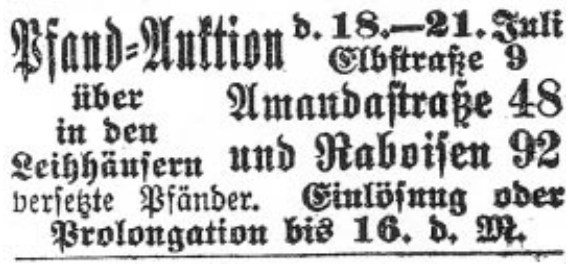

2

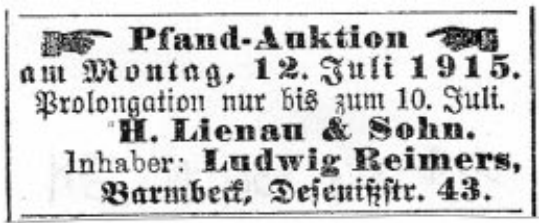

3

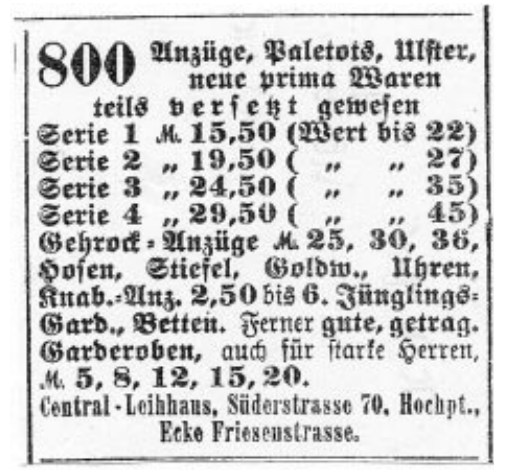

4

Figure r. These examples of advertisements of private pawnshops in Hamburg are drawn from the local social-democratic newspaper. Their modest size and appearance is typical of all advertisements for pawnshops - a fact that sustains the argument that these were mostly only modest enterprises. In example no. I (that consists of three separate advertisements for three different pawnshops) the first (at the top) gives just the name of the shop and its address, while the two others promise customers-to-be "the highest credit on valuables of any kind" or just "the highest credit". In small print the third shop also announces the selling of "watches, silverware, jewellery, and forfeited goods of any kind". Examples no. 2 and 3 advertise auctions of forfeited goods and remind clients to renew their contracts before the given day of expiry. Example no. 4 is an advertisement of a pawnshop that was combined with a different trade. In this case the shop sold not only forfeited clothes but also new suits and cloaks for men and boys. Customers are promised a real bargain: they have to pay only for two-thirds of the "real value" of the garments. All the shops were situated in proletarian neighbourhoods.

No. I from Hamburger Echo, 226 (26.9.19I5); no. 2 from ibid., I63 (I5.7.19I5); no. 3 from ibid., I5s (6.7.19I5); no. 4 from ibid., 163 (I5.7.19I5). 
Saints Day while only 308 credits were paid off on average per working day. Each of these customers did not want "to appear to be more destitute than his equals" at least on these important holidays. $4^{\circ}$

Besides this, there existed an seasonal pattern of pawning: in April and May pawnbrokers always experienced an increased influx of new pledges while a particularly large number of goods was redeemed in October. Obviously people pawned goods - mostly clothes - which were of no use to them during summer and got hold of them again when winter returned. ${ }^{4 \mathrm{I}}$ This offered the additional advantage that the seasonal pledge was out of the way when it was not in use - an aspect of some importance since, more often than not, the lodgings of workers' families lacked storage room.

Weekly pawning on a regular basis, which was very common in Great Britain - a very costly affair for the customer because the rates of interest added up over the course of time - seems to have been rare in Germany. Once again the evidence for this is of rather questionable value: most public pawnshops reported that only a small portion of their customers were weekly regulars, but things may have been different at private shops. ${ }^{42}$

In contrast, the link between pawning and economic trends can be more easily ascertained. Surprisingly enough this was not a contrary development: pawning was not booming in times of economic crisis and it did not deteriorate when employment figures and wages were high. On the contrary, trends in pawning closely followed the increase or decrease of economic activity. Every economic downturn also hit the pawnshops, i.e. the number of new pledges decreased significantly. According to the Augsburg Städtische Pfandleibe, this was even true when the local economy suffered from strikes and lockouts. ${ }^{43}$ The same direct link could be observed in boom times: when industry and commerce thrived the pawnshops thrived as well. 44

Economic downturns also had much less impact on the number of forfeited goods than might be assumed. During a slump far more contracts were renewed by payment of interest due than during periods when the economy was running smoothly, 45 but in the long run the great majority of

40. Zach, Pfandleihgeschäft, p. 55 .

41. Saulacher, Geschichte, p. 80; Cuneus, Leibhäuser, pp. 53-54.

42. Statistisches Jabrbuch Deutscher Städte, vol. Io (Berlin, I902), pp. I 77 f. On weekly pawning in Great Britain compare Tebbutt, Making Ends Meet, pp. 7, I4-I 5, I 7, 3 I; Johnson, Saving, pp. I66, I 80-I 8 I.

43. Zach, Pfandleihgeschäft, p. 58 .

44. A. Gramkow, "Leihhäuser", in Ludwig Elster et al. (eds), Handwörterbuch der Staatswissenschaften. 4. gänzlich umgearbeitete Auflage (Jena, 1925), vol. 6, pp. 333-345, 34I.

45. Compare the figures in Statistisches Jabrbuch Deutscher Städte, vol. I4 (Berlin, 1907), pp. 330-33 I; Statistisches Jahrbuch Deutscher Städte, vol. Io (Berlin, I902), pp. I86- I87. 
all pledges was redeemed regardless of the prevailing economic situation. In Hamburg this figure was never less than ninety-four per cent at the Staatspfandleibe over the course of the years and eighty-eight per cent on average at the private pawnshops. ${ }^{46}$ However, to judge these figures accurately it is necessary to point out that the redeemed pledge was not necessarily returned into the hands of the person who had pawned it. A pawn ticket could be sold, since in most parts of Germany it did not carry the borrower's name. Even in Prussia, Germany's largest Staat, where pawnbrokers had to enter a name in the form when they accepted a pledge, this was of no consequence: the name that the customer announced was not checked, neither at the first instance, when the valuable in question was pledged, nor when the credit was paid off to redeem the pledge. So pawn tickets were traded also in Prussia. ${ }^{47}$ Naturally police authorities, as well as middle-class politicians, regarded this practice as an invitation to crooks and fences, but all efforts to bring about a change failed at the remonstrances of pawnbrokers that any alteration would be the end of their business. ${ }^{4}$ It is therefore impossible to say precisely which pledge was redeemed by the borrower and which had been purchased in the form of the pawn ticket by a different person.

It was not difficult to trade in these tickets. When the ticket came from a municipal pawnshop it could be sold to a private pawnbroker (the municipal pawnshops were so cautious in estimating the value of pledges that the private pawnbroker could hope for a profit when he redeemed the pawned goods) or to those venturesome enough to buy a pig in a poke. According to contemporary observers, workers were quite keen for such bargains despite the obvious risk. As a rule the price for a pawn ticket was less than twenty per cent of the credit the pledge secured - a rate which in any case made this a very bad deal for the seller. ${ }^{49}$

Despite the practice of trading pawn tickets it can be assumed that most redeemed pledges once again became part of the household of their initial owner. This is suggested by the fact that redemption more often than not followed very quickly on pawning. At the Munich municipal pawnshop on average forty-three per cent of all credits were paid off during the first two months of the contract's six-month term in the years 1905-1908; a further twelve per cent of the pledges were redeemed during the third

\footnotetext{
46. Calculated on the basis of Tabelle (no. 5).

47. Patterson, Die gegenwärtige Lage, pp. 218-219; Stellungnahme des Lombard-Inspektors (no. 38). In most other Bundesstaaten no name had to be entered on the pawn ticket.

48. Compare, for example, Denkschrift des Vereins der Pfandleiher Hamburgs, September i 1 I I, StA Hamburg Senat Cl.VII Lit.C c nr. 5, vol. 67, conv. I; Denkschrift des Vereins der Pfandleiher Hamburgs, June i 912 , ibid.

49. Zach, Pfandleibgeschäft, p. I02. Tickets from municipal pawnshops sold at fifty per cent of the credit.
} 
month. ${ }^{\circ}$ Customers of the Hamburg private pawnshops were so eager to regain their goods that on average they had to pay only 7.5 per cent interest on their credit - very much to the dismay of the pawnbrokers, who regarded this as inadequate earnings. In any case, most customers in Hamburg redeemed their pledges after two or three months as well, although the term of the contract was usually twelve months in these cases. $^{\text {II }}$

It seems very unlikely that anyone would have sold his or her pawn ticket within a few weeks, when there were still several months left to live in hope of an improvement in the economic situation. Very probably people only considered this bargain - which was, as noted above, from their point of view a very bad deal - when the contract was due to expire and still no cash was available to redeem the pledge. As the figures just given demonstrate, this applied to just a minority of all cases of pawning. For the most part there was nothing adventurous or desperate to the act of pawning since most people were able to retrieve their valuables within a rather short period of time.

\section{SOME CONCLUSIONS: PAWNING AND THE ECONOMY OF WORKING-CLASS HOUSEHOLDS}

Maybe we can now summarize some major points and draw some conclusions. Obviously pawning was a common part of the household economy of proletarian families during the years of the Kaiserreich, although we know very little about how workers felt about it and whether it was used by "respectable" working-class families as well as by the "rough" parts of the proletariat. Loans gained by pawning were for the most part on a very modest scale. Clearly enough, the "ordinary" working-class family was not equipped with goods that were valuable enough to secure a larger credit. In most cases inexpensive watches and jewellery as well as the "Sunday best" seem to have been the most precious items among their possessions. Therefore it is unlikely that pawning served to secure the proletarian household in periods of real hardship. A credit worth only two day's wages or even less was no great relief when a family was hit by long-term unemployment or by severe sickness, even if several goods were pawned.

In times of real hardship proletarian families tried to avoid the accumulation of debts - clearly because they felt that this could easily lead to complete disaster. They strictly economized on their spending most commonly by cutting down all expenses in a rather schematic way, not by establishing a completely new way of consumption - and they tried

5. Denkschrift des Vereins der Pfandleiher Hamburgs, September I9I I (no. 48). 
to raise additional income: other members of the household besides the

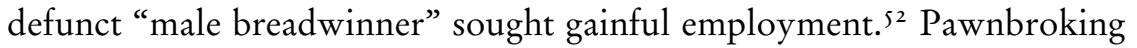
- a form of indebtedness - was not a central part of this strategy of stretching resources. As I would argue, the pawnbroker's loans served a different economic purpose. The fact that the number of new pledges declined during economic downturns and increased when the economy was running smoothly helps to sustain this argument. Contrary to a widespread contemporary belief, pawning was in most cases only considered when it seemed very likely that the borrower would be able to redeem the pledge in due course. It was therefore part of a rather stable economic situation and expressed a trust in the immediate future - that is for the course of the next months. Insecurity of prospects taught people to act more cautiously and persuaded them to refrain from pawning.

There is no better proof of this point than the development of pawnbroking during the First World War. Although the mobilization brought about a sharp increase in the unemployment figures during the first months of the war, all German pawnshops had to cope with an abrupt drop of nearly fifty per cent in the number of new contracts immediately after August I9I4. Furthermore, pawnbroking declined steadily up to I9I 8 despite - or, as I would argue, because of - the widespread economic hardship among German working-class families. ${ }^{53}$

Pawning, it can be concluded, was more often than not used as a means of short-term additional income; it helped families to pay for some minor unexpected expenditure, to buy something that was urgently needed in advance and/or it protected them against the very common minor fluctuations in family income over the course of the year. ${ }^{54}$ It could not guard them against real need and against the major risks of working-class life - long-term unemployment, a case of severe sickness in the family and old age. On average, German proletarian families before the Great War simply lived in far too modest circumstances to secure such protection. The fact that pawnshops were especially rare in the new industrial cities of Germany, such as Bochum or Gelsenkirchen, is therefore not as surprising as it may appear at first glance: these were towns that were dominated by the "rough" working class, by unskilled, unmarried young men and young couples with children; migration and changes of employment were extremely frequent, stable jobs for skilled and better paid workers were scarce. Pawnbrokers could not prosper in these surroundings. They

52. Compare the budgets of thirty-nine families of unemployed men in Die Lebenshaltung von 2000 Arbeiter-, Angestellten- und Beamtenhaushaltungen. Erbebungen von Wirtschaftsrechnungen im Deutschen Reich vom Jahre 1927/28. Bearb.im Statistischen Reichsamt, 2 vols (Berlin, I932), vol. I, pp. I69-I76. I see no reason why the results of this survey that was carried out in the late 1920 s should not be true for the prewar years as well.

53. Compare Führer, Kreditinstitut, pp. 20-2 I.

54. Compare for these fluctuations, for example, Ritter/Tenfelde, Arbeiter, pp. 498-499. 
thrived - to repeat that again - not on working-class destitution, but on the very modest "affluence" proletarian families were able to achieve in the era of industrialization before the First World War.

If this argument is taken for granted, there would be more to the difference in the number of pawnshops in Great Britain and in Germany than just the stricter public regulation of pawnbroking in the latter country. The fact that so many more pawnshops existed in Britain than on the continent would then point to significant differences in proletarian standards of living between the two societies in question. Since we do not have comparative studies on working-class life in Great Britain and Germany it is perhaps best to express this in the form of a question: could it be that British working-class families in the late nineteenth and early twentieth centuries were considerably better off than their German counterparts in term of chattels and of secure economic prospects? Due to the lack of scholarly studies that compare the proletarian way of living in the societies in question I am in no position to answer this question, but I think I have at least been able to demonstrate that such a comparative examination might well turn out to be very rewarding. 55 Hopefully, this essay will thus help to foster an interest in studies of working-class life that transcend the narrow boundaries of national history.

55. Most comparative studies in the field of working-class history have been centred on the history of the labour movement. Compare, for example, Marcel van der Linden and Jürgen Rojahn (eds), The Formation of Labour Movements, I870-1914: An International Perspective, 2 vols (Leiden, I990). As rare examples of differently focused studies, see John Breuilly, "The Labour Aristocracy in Britain and Germany: A Comparison", in idem, Labour and Liberalism in Nineteenth-Century Europe: Essays in Comparative History (Manchester [etc.], I992), pp. 2675; Richard Biernacki, The Fabrication of Labour: Germany and Britain, I640-1914 (Berkeley, CA, 1995). 